\title{
AN ANALYSIS OF IMPLICATURES FOUND IN WHATSAPP STORIES
}

\author{
Afiifah Al Rosyiidah \\ Department of English, Faculty of Social and Cultural Sciences \\ Universitas Trunojoyo Madura \\ e-mail: afiifah.rosyiidah@trunojoyo.ac.id
}

\begin{abstract}
This study focuses on implicatures found in the WhatsApp stories. This study aims to find and explain types of implicatures found in WhatsApp stories using the theory proposed by Yule (1996). This study employs qualitative design as the research design. In addition, content analysis is applied to obtain the data in which the writer becomes the key instrument of the study. Interactive data analysis, then, is conducted to analyze and explain the data. The data of the study are taken from WhatsApp stories that appears in the writer's WhatsApp application. This study shows the findings of the types of implicatures. The data are classified into four types of implicatures: generalized conversational implicatures (5 data), particularized conversational implicatures (7 data), scalar implicature ( 2 data), and conventional implicatures (1 datum).
\end{abstract}

Keywords: Implicatures, Types of Implicatures, WhatsApp Stories. 


\section{INTRODUCTION}

Communication has a vital role in the social life. People communicate with others to deliver their message or intention by using language (can be written or oral). Sometimes, what is said by the speaker directly refers to what the speaker's want. However, it is possible to find a phenomenon when the speaker does not say their intended message to the listener directly. The speaker may have any reason why she/he does not say the wants immediately. It can be in order to keep culture or to keep politeness. It will be a problem if the listener does not catch the speaker's intention well. In other hand, the aim of communication is to deliver what the speaker's want to the listener. The communication cannot run effectively when they do not have the same understanding on their intended meaning.

To communicate via online media is something common today. There are many social media to communicate with others. Recently, one of popular social media mostly used to communicate with others is WhatsApp. Most people from teenagers to old people use this application to greet others, ask about their job, or have online learning. This application is also equipped with WhatsApp Stories. It is usually used to share their feeling (good or sad), promote something, inform any information, and others. Surely, they have intended meaning when they share their story via WhatsApp stories. We can use implicature to be aware on what the speaker's intended meaning.

Implicature is one of scope in Pragmatics. Levinson (1983) states that pragmatics is the study of the use of language communication. In this study, people try to see the relation between language and contexts. While, implicature has been defined well by some linguists. Grice (in Levinson, 1983) defines implicature as "what the speaker can implies, suggests or means as something different from what the speaker literally says". Therefore, to understand a speaker's message, the hearer should be able to guess the intended meaning because sometimes the speaker delivers information more than what she or he is really said. The speaker may deliver the message both explicitly and implicitly. In addition, Yule (1996) argued that implicature is an additional expressed meaning, or it is something that must be more than just the words mean. Moreover, it is a primary example of more being communicated than is said.

Yule (1996) wrote that implicature has some types: 1) Conversational implicature is implicature that is based on the maxims and contexts. It happens when a speaker meaning can differ from what is said, depending on the context of the conversation. Conversational implicature has two kinds: 1.a.) Generalized conversational implicature happens when the hearer does not need to have a special knowledge to estimate the additional conveyed meaning. For the example, Fahmi asks Dila whether she invites her friends Bella and Cathy to the party or not. Dila answers "I invited Bella". It means that Fahmi automatically knows that Dila only invites Bella and she does not invite Cathy. 1.b.) Particularized conversational implicature is a conversational implicature which is in contrast with the generalized conversational implicature. This implicature happens when the speaker is saying something and implicitly the hearer is giving the response. So, the speaker must be able to interpret the hearer's statement based on the context. For example: Lala ask Mila to come to the party tonight, but Mila answers: My parents will come tonight." 2) Scalar implicature happens when the speaker utters the word from the scale which is the most informative and truthful in any case. For example: "I have studied Linguistics, and I have completed some of the required courses." From this utterance, the word "some" means that I make an implicature that not all courses have been completed. 3) Conventional implicature is also related to specific words (but, yet, and, even) and those words may 
carry additional conveyed meaning when they are used. In addition, this type is not based on Pragmatics principles or maxims, and it does not need special context for its interpretation. For example: "Marry suggested yellow, but I chose blue". This utterance implicates that there is a contrast opinion between Marry and I.

There are some previous researches related to this study. First, Implicatures In Interviews In Kenyan Print Media: A Case Of The East African Standard by Mayora and Mukhwana (2014). Second, Types Of Implicature In Informal Conversations Used By The English Education Study Program Students by Rahayu and Safnil (2016). Both of these studies are different from this study. This study analyzes types of implicatures found in WhatsApp stories based on George Yule's theory.

\section{METHODOLOGY}

The writer employed a qualitative research in this study. The source of data chosen in this study is WhatsApp stories appeared in the writer's WhatsApp application released on April 6th, 2020. The data of this study are utterances which contain implicatures found in the WhatsApp stories. In collecting the data, the writer applied content analysis. The writer then analyzed the data based on Miles and Huberman's interactive data analysis which consists of data collection, data reduction, data display, and conclusion. In data collection, the writer collected the data based on the statement of the research problems. The data were taken from WhatsApp stories appeared in the writer's WhatsApp application. Then in data reduction, the data were selected and reduced by classifying them into types of implicatures. Therefore, the data which were not appropriate or did not belong to implicatures are omitted. The next process is data display where the writer explained more the data in discussion based on the types of implicatures. The last process is drawing conclusion/verification. The conclusion was explained based on the result of the data analysis. In addition, the writer provided some suggestions.

\section{FINDINGS AND DISCUSSIONS}

In findings, the writer collected utterances indicating implicatures found in some WhatsApp stories. The writer found fifteen data and classified them based on the types of idioms. To make easier, the writer used table in displaying the data. Therefore, the data classified into types of implicatures: generalized conversational implicature, particularized conversational implicature, scalar implicature, and conventional implicature proposed by Yule (1996) are shown in Table 1.

Table 1 shows that all types of implicatures are available for the data found in the WhatsApp stories. Based on the frequency of each type, it can be seen that all types of implicatures are found in the source of data. Based on the data, particularized conversational implicature becomes the most frequent type of implicature including all data found, it has seven data. The next position provides that generalized conversational implicature is in the second position having five data of the total fifteen data found. Then, scalar implicature has two data of the total fifteen data found, and the lowest frequent type of implicature is conventional implicature having one datum of the total fifteen data found. 
Table 1.

\begin{tabular}{|c|c|c|c|c|c|}
\hline \multirow[t]{2}{*}{ No. } & \multirow[t]{2}{*}{ Data } & \multicolumn{4}{|c|}{ Types of Implicatures } \\
\hline & & $\begin{array}{c}\text { Generalized } \\
\text { conversational } \\
\text { implicature } \\
\end{array}$ & $\begin{array}{c}\text { Particularized } \\
\text { conversational } \\
\text { implicature } \\
\end{array}$ & $\begin{array}{c}\text { Scalar } \\
\text { implicature }\end{array}$ & $\begin{array}{c}\text { Conventional } \\
\text { implicature }\end{array}$ \\
\hline 1. & $\begin{array}{l}\text { Seporsi sop merah/ } \\
\text { serantang....... } 25 k\end{array}$ & & & $\sqrt{ }$ & \\
\hline 2. & $\begin{array}{l}\text { Request menu untuk } \\
\text { Rabu bsk....Close nnt } \\
\text { sore jm } 17.00 \text { wib... }\end{array}$ & $\sqrt{ }$ & & & \\
\hline 3. & $\begin{array}{l}\text { Baking for this } \\
\text { morning... for snack } \\
\text { time }\end{array}$ & & $\sqrt{ }$ & & \\
\hline 4. & $\begin{array}{l}\text { Akan aku balas } \\
\text { kebaikanmu dengan } \\
\text { doa dimalam Jum'at } \\
\text { nanti. }\end{array}$ & & $\sqrt{ }$ & & \\
\hline 5. & $\begin{array}{l}\text { Detail sudah ada di } \\
\text { gambar yaa, ada } \\
\text { pilihan warna lain. } \\
\text { Hemat ongkir se } \\
\text { Indonesia. }\end{array}$ & $\sqrt{ }$ & & & \\
\hline 6. & $\begin{array}{l}\text { Hancur leburrr sudah } \\
\text { topakq .....(emoticon } \\
\text { menangis) hiks } \\
\text { hiks....bell...(emoticon } \\
\text { meninju) }\end{array}$ & & $\sqrt{ }$ & & \\
\hline 7. & $\begin{array}{l}\text { Saudara rasa temen, } \\
\text { temen curhat, temen } \\
\text { main, masa karantina } \\
\text { di rumah \#dirumah }\end{array}$ & $\sqrt{ }$ & & & \\
\hline 8. & $\begin{array}{l}\text { Ketauhilah nak kanak } \\
\text { bahwa dalam } \\
\text { pembelajaran online } \\
\text { ini, tidak hanya kalian } \\
\text { yang terforsir tenaga } \\
\text { dan quotanya. Kita } \\
\text { berjuang dengan } \\
\text { segala keterbatasan } \\
\text { yang ada... }\end{array}$ & & & & $\sqrt{ }$ \\
\hline 9. & $\begin{array}{l}\text { Kuliah daring } 4 \\
\text { kls....makul Bhs } \\
\text { Inggris, PKN, EYL... }\end{array}$ & & $\sqrt{ }$ & & \\
\hline 10. & $\begin{array}{l}\text { Ayo saling } \\
\text { mengingatkan "pakai } \\
\text { masker"!!!! }\end{array}$ & & $\sqrt{ }$ & & \\
\hline 11. & $\begin{array}{l}\text { Mau bikin disinfektan } \\
\text { dari PGA? Sudah tau } \\
\text { caranya? Kalau } \\
\text { belum tau, sini beli } \\
\text { PGAnya. nanti aku } \\
\text { bonusin pengencer n } \\
\text { cara bikin nya... }\end{array}$ & & $\sqrt{ }$ & & \\
\hline 12. & $\begin{array}{l}\text { Barusan lihat. } \\
\text { Ternyata ga boleh itu } \\
\text { krn bahan nya. Ada } \\
\text { klorin dll. Kalo }\end{array}$ & $\sqrt{ }$ & & & \\
\hline
\end{tabular}




\begin{tabular}{|c|c|c|c|c|c|}
\hline & $\begin{array}{l}\text { disinfektan pake PGA } \\
\text { ya InsyaAllah tidak } \\
\text { berbahaya. PGA kan } \\
\text { Alcohol FoodGrade }\end{array}$ & & & & \\
\hline 13. & $\begin{array}{l}\text { Beli } 5 \text { L harga lebih } \\
\text { murah ya cin.. }\end{array}$ & $\sqrt{ }$ & & & \\
\hline 14. & $\begin{array}{l}\text { Siapa tw ada } \\
\text { pangeran berkuda } \\
\text { putih lewat haha }\end{array}$ & & $\sqrt{ }$ & & \\
\hline 15. & $\begin{array}{l}\text { PR nya } \\
\text { buanyak...harus } \\
\text { semangat... }\end{array}$ & & & $\sqrt{ }$ & \\
\hline & Frequency & 5 & 7 & 2 & 1 \\
\hline
\end{tabular}

\section{Types of Implicatures}

As Yule (1996) wrote, the types of implicatures are generalized conversational implicature, particularized conversational implicature, scalar implicature, and conventional implicature. Based on the data found, particularized conversational implicatures become the most frequent type of idioms, followed by generalized conversational implicatures, scalar implicatures, and conventional implicature. In this discussion, the writer analyzed each of the data classified into those types of implicatures based on the definitions proposed by Yule (1996).

\section{Generalized Conversational Implicatures}

Generalized conversational implicature happens when the hearer does not need to have a special knowledge of the context to estimate the additional conveyed meaning (Yule, 1996). In this type of implicatures, there are the total five data explained. The writer analyzed two data as the representatives of the total five data which are explained further in the discussion below.

\section{Datum 2: "Request menu untuk Rabu bsk....Close nnt sore jm 17.00 wib...."}

This utterance belongs to generalized conversational implicature. When the writer wrote this utterance, the readers can catch the writer's intended meaning without background knowledge of context. From this utterance, it implies that if the readers want to order the food for Wednesday, they must inform the seller/the writer not more than 05.00 p.m. If they inform to order the menus at 08.00 p.m., they will not enjoy the food from the seller on Wednesday. So, without a special knowledge, the readers can understand what the writer's want. Therefore, datum 2 is categorized as generalized conversational implicature.

\section{Datum 7: "Saudara rasa temen, temen curhat, temen main, masa}

\section{karantina di rumah" \#dirumah}

This utterance is another datum that is categorized as generalized conversational implicature. When the writer wrote this utterance, the writer implies that she has good relation with one of her family (cousin). She spends every single time with the cousin during she is at home because of quarantine. When the readers read this WhatsApp story, they can understand it without having a background knowledge of the context. So, datum 7 is classified into generalized conversational implicature. 


\section{Particularized Conversational Implicatures}

Particularized conversational implicature is a conversational implicature which is in contrast with the generalized conversational implicature. This implicature happens when the speaker is saying something and implicitly the hearer is giving the response. So, the speaker must be able to interpret the hearer's statement based on the context (Yule, 1996). There are seven data found that can be classified into this type of implicatures. Two data are explained in detail below.

\section{Datum 4: "Akan aku balas kebaikanmu dengan doa dimalam Jum'at nanti”.}

The utterance can not be understood well by the readers if the readers does not know the context. Why the writer must pray in the Thursday night is the context that must be known by the readers. The context is some Muslims has a tradition to have tahlilan or praying together on Thursday night. It is a special night to pray to God, and they believe it is special time to pray to God. So, the writer prays for someone on special night because he has big gratitude to the person. For the reason, the utterance is categorized as particularized conversational implicature.

\section{Datum 6: "Hancur leburrr sudah topakq.....(emoticon menangis) hiks hiks....bell..."(punch emoticon)}

Before understanding this utterance, the readers must recognize the background knowledge. Why the writer must be sad and use crying emoticon to express her utterance can be understood by the readers if they know the context. The writer is a mother whose a toddler namely Felly (she calls her Belli). She wanted to make a food namely topak/lontong. When she made the packages of topak that made from coconut leaves, her daughter ruined them. So, this utterance implies that the writer shares her feeling of angry and sad because of this problem. This utterance is appropriate to be the type of particularized conversational implicature.

\section{Scalar Implicatures}

Scalar implicature happens when the speaker utters the word from the scale which is the most informative and truthful in any case (Yule, 1996). There are two data found that can be classified into this type of implicatures. A datum is explained in detail below.

\section{Datum 1: "Seporsi sop merah/ serantang....... 25k".}

The utterance contains words from the scale, they are the word "seporsi" and "serantang". This utterance means that the readers will only get a bowl of red soup by paying Rp. $25.000,00$. They will not get more than that. If they want to get two bowls of red soup, they must pay Rp.50.000,00. For this reason, the utterance is categorized as scalar implicature.

\section{Conventional Implicature}

Conventional implicature is also related to specific words (but, yet, and, even) and those words may carry additional conveyed meaning when they are used. In addition, this type is not based on Pragmatics principles or maxims, and it does not 
need special context for its interpretation (Yule, 1996). There is only a datum found that can be classified into this type of implicatures. The datum are explained in detail below.

Datum 8: "Ketauhilah nak kanak bahwa dalam pembelajaran online ini, tidak hanya kalian yang terforsir tenaga dan quotanya. Kita berjuang dengan segala keterbatasan yang ada..."

The utterance is related to specific words "and", this word brings additional communicated meaning when it is used. This speaker implies that when she and her students conduct online learning, they need many energies. They need not only many energies but also many quotas to conduct online learning. There is additional conveyed meaning shown here. So, the utterance is suitable to be categorized as conventional implicature.

\section{CONCLUSION}

The aims of this study are to find out and to explain the types of implicatures found in WhatsApp stories. The writer found 15 data which are included as the entries of the implicatures. In analyzing the types of implicatures, the writer used the theory of types of implicatures proposed by Yule (1996). The types of implicatures are divided into four types: generalized conversational implicatures, particularized conversational implicatures, scalar implicature, and conventional implicatures. Related to this theory, the writer found 5 data belonging to generalized conversational implicatures, 7 data belonging to particularized conversational implicatures, 2 data belonging to scalar implicature, and 1 datum belonging to conventional implicatures. From those findings, the writer concluded that particularized conversational implicature becomes the most frequent type of the implicatures found in the WhatsApp stories.

\section{REFERENCES}

Leech, G. (1983). Principles of pragmatics. London: Longman.

Levinson, S.C. (1983). Pragmatics. Cambridge: Cambridge University Press.

Mayora, J. \& Mukhwana, A. (2014). Implicatures in interviews in Kenyan print media: A case of the East African standard. International Journal of Education \& Research, 2(08), 549-562.

Mey, J.L. (1993). Pragmatics an introduction. Oxford: Blackwell Publishing.

Rahayu, E.S. \& Safnil. (2016). Types of implicature in informal conversations used by the English education study program students. Journal of Applied Linguistics and Literature, 1(1), 65-83.

Yule, G. (1996). Pragmatics. USA: Oxford University Press.Lyotard, J.F.(1982). The Postmodern Condiition: A Report of Knowladge. Manchester: University Of Menchester.hlm.xi. 